\title{
The 020 Mode in Electronic Commerce
}

\author{
Jia $\mathrm{Li}^{1, \mathrm{a}^{*}}$ and Wei Jian $\mathrm{Mo}^{2, \mathrm{~b}}$ \\ ${ }^{1}$ Xinhua College of Sun Yat-sen University, Guangzhou 510520,China \\ ${ }^{2}$ Xinhua College of Sun Yat-sen University, Guangzhou 510520,China \\ a 874633154@qq.com, ${ }^{\text {b } 472252720 @ q q . c o m ~}$
}

Keywords: Internet; Online business; O2O mode; Traditional industries

\begin{abstract}
With the rapid development of mobile Internet, the degree of integration of online business and lines entities has become more and more closely. Thus it is forming a new model: $\mathrm{O} 2 \mathrm{O}$ mode. For this reason, this paper analyzed the $\mathrm{O} 2 \mathrm{O}$ mode. And this paper is using actual case to analyze it. At the end, this paper is analysis it with the development trend. And we are discussed it with the existing problems. On this basis, we are proposing a number of related policies.
\end{abstract}

\section{Introduction}

According to the analysis report the china Mobile Internet Market Outlook and Investment Strategy, it was show that the number of Internet users in China reached 538 million, of which mobile phone users reached 388 million. The number of mobile phone users beyond the desktop internet users at the first time. In addition, MIIT statistics: the number of smart phone users reached about 350 million in 2012. And the number of registered Internet banking is breakthrough 190 million. The number of all kinds of social application users was about 300 million. Instant messaging users have even break through 460 million. This means that the mobile Internet ushered in a period of rapid development [1-3].

At the same time, we can see that the decrease of flow rates in the mobile Internet. User needs to get a qualitative leap in the smart phone [4]. User's usage gradually expanded from the traditional reading to the emerging field of online games, video browsing, and social interaction, etc $[5,6]$. Nowadays, user is more and more accustomed to the smartphone as connection of real life and Internet [7]. A mobile phone companies $\mathrm{CEO}$ in Taiwan said: On the air, pigs can fly. $\mathrm{O} 2 \mathrm{O}$ mode is Online to Offline. For traditional businesses, $\mathrm{O} 2 \mathrm{O}$ mode is this pig. It was offline business opportunities together with the Internet. And Let the Internet be the front desk to the offline transactions. So the offline service can use the online to attract customers, and the consumers can use the online to screening Service. Checkout can be completed online. That was change the existing business model.

\section{Difference between $\mathrm{O} 2 \mathrm{O}$ made and B2C、C2Cmade}

O2O made want to create a "consumer experience" model. Consumer is online payment, goods or services to buy the offline, and various forms of credentials to the store to pick up or enjoy the service. Advantages of $\mathrm{O} 2 \mathrm{O}$ mode:

Without logistics costs

Businesses can easily grasp customer information

Easy to promote products 
Customers and business communicate are no obstacles

$\mathrm{O} 2 \mathrm{O}$ mode can help consumers to save time on the screening, settlement.

Compare with $\mathrm{O} 2 \mathrm{O}$ made, $\mathrm{B} 2 \mathrm{C}, \mathrm{C} 2 \mathrm{C}$ mode are main mode of e-commerce. They have in common is the business to consumer goods to the hands of consumers by way of distribution. In the whole process, there is the cost of logistics. But QOS on logistics will affect the consumer's satisfaction.

\section{Case Analysis}

Alibaba is an international Internet company that was created by the Chinese people. This paper was suing the case of Alibaba cooperation with Yantai business. Alibaba announced that it will invest 5.37 billion Hong Kong dollars to the Yantai business in March 30, 2014. That can integrate the advantages of both resources. And it will benefit to constructed online and offline commercial system in the future. Those promote commercial entities and economic integration of the Internet.

Speaking from operations, the core driver of Alibaba $\mathrm{O} 2 \mathrm{O}$ is the Business (Tmall online and Yantai brand shop offline) Terminal implementation experience and logistics self-pick up function, category hardly changes, channel concentrated in offline brands like Yantai.

From the point of view of information integration, Tmall have many promotional programs completely determined by the brand side. For example: Procurement strategy, Inventory Policy, Replenishment Strategies, etc. It is test supply chain capabilities online and offline under the brand side.

Drainage from the mobile client view, Alibaba invested heavily in Weibo, High German, Tintin concessions, etc. At the same time, it was achieve account associated with mall and Taobao. So it is worthy of attention and study.

From the logistics point of view, The $\mathrm{O} 2 \mathrm{O}$ made like the Tmall and Yantai. There will be three kinds of logistics services. One is the traditional offline experience and Online shipped in logistics center. The second is picking themselves goods in the offline. The third is store made express in the offline. These three models are focused on logistics operations management. It is worth mentioning that Alibaba and many related financial institutions to work together to build an open logistics platform in May 28, 2013. It hopes to achieve is: 24 hours in any one area to do service in the country.

Through analysis of the case, we can found that the reasons of the o2o business development bad in a few years ago. Due to immaturity of networking technology and lack of knowledge o2o mode. Alibaba by building a logistics platform to achieve real-time delivery. It is a large extent attracted more customers. And efficient use of resources online and offline.These are the reasons for the success of Alibaba.

\section{Trend of 020 development}

With the wave of Group buy, O2O mode is quickly spread to every corner. At the same time, it is profoundly changed the business practices of the traditional economy. And it is changing habits of consumers in imperceptibly. In order to better analyze, we investigated the market economy in recent years. The resulting data is shown below. 


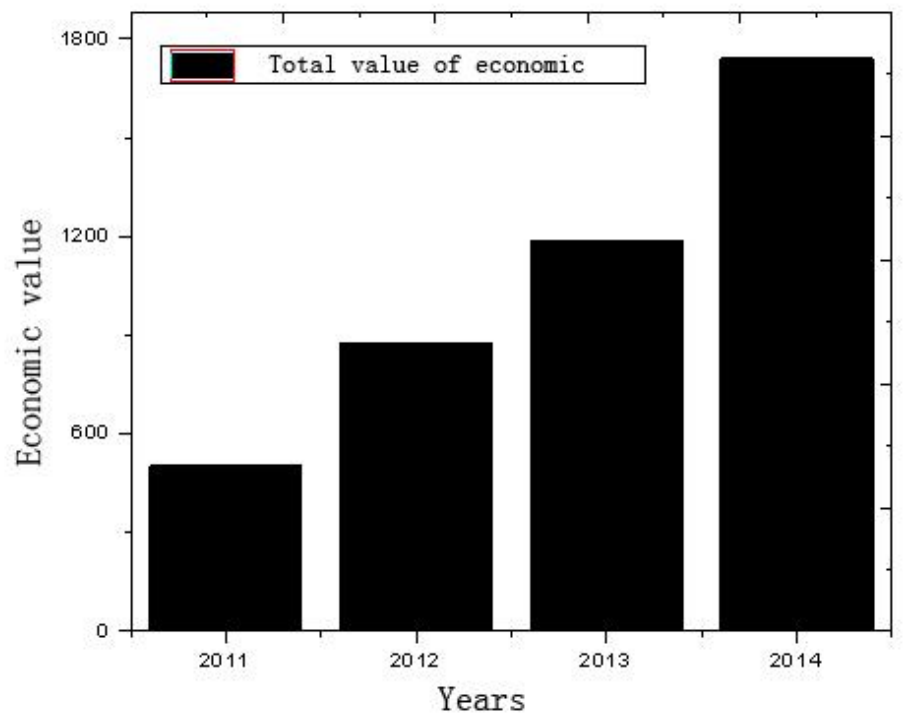

Figure. 1 Total value of $\mathrm{O} 2 \mathrm{O}$ market size

From the data obtained, we can see that the total value of market size continues to grow. In 2011, Total value of $\mathrm{O} 2 \mathrm{O}$ market size is 58.7 billion yuan. In 2012, Total value of $\mathrm{O} 2 \mathrm{O}$ market size is 87.5 billion yuan. In 2013, Total value of $\mathrm{O} 2 \mathrm{O}$ market size is 118.8 billion yuan. In 2014, it has exceeded 150 billion yuan. I believe will continue to grow in the coming years.

\section{Problems and Countermeasures of the $\mathbf{O 2 O}$ mode}

By observing the current market economy, $\mathrm{O} 2 \mathrm{O}$ mode explosive development will bring a series of problems. Therefore, those problems will limit the development of $\mathrm{O} 2 \mathrm{O}$ mode.

Innovation of 020 model. Nowadays, Domestic business enterprise for the understanding of O2O mostly still in the stage Group buys. In 2011, group buy site are soared from over seventeen hundred to over five thousand. That would be leads to trouble ahead of the arrival. Therefore, How to avoid the occurrence of this phenomenon? It was important issues need enterprises to solve. According to the study of e-commerce, we can be found that $\mathrm{O} 2 \mathrm{O}$ model is designed to enhance business communication with users [8]. Therefore, companies should need to consider about how to effectively attract customers. And develop an effective marketing strategy to attract consumers. And they should focus on sales path and efficiency. From the above case we can see that Alibaba is very seriously $\mathrm{O} 2 \mathrm{O}$ mode. This is one of the main reasons for their success.

Strict control of quality and speed. From the foregoing case can be seen, Alibaba hopes to build a strong logistics platform. In our daily consumption, affect our consumption is the speed of delivery and quality. Alibaba is combination of offline and online. Effective solution to the problem of supply, and it can attract more customers to the merchant. But businesses in order to earn more money at sometimes, they will reduce the quality of the goods review. It must cause great harm for the consumers. Once consumers has got a bad consumer experience, which will be to question the businesses. Leading business $\mathrm{O} 2 \mathrm{O}$ model has been questioned [9]. Therefore, businesses should pay close attention to the quality when faced with this problem. We can enhance the speed of cargo transportation on the basis of the quality. It is worth learning from Alibaba.

Issue of integrity. At present, many enterprises have the credibility issue in china. These issues are emerging. For example, Escaped leave after payment, Description of the goods does not match with the actual, limiting online and tempting offline, etc. These problems not only have a negative impact on individual $\mathrm{O} 2 \mathrm{O}$ enterprises. Even seriously affect the development of the whole $\mathrm{O} 2 \mathrm{O}$ industry [10]. Therefore, state should establish mechanisms for integrity $\mathrm{O} 2 \mathrm{O}$ industry. Government 
can use the law to limit the deception. Establish a sound monitoring mechanism, the results of monitoring will be timely publication to consumers.

\section{Summarize}

The study found $\mathrm{O} 2 \mathrm{O}$ mode by changing the traditional trading patterns. It is completely open up the link online and offline. By studying Alibaba, to analyze the $\mathrm{O} 2 \mathrm{O}$ is importance of corporate. And according to the problems of our country o2o model, this paper has put forward some suggestions to $\mathrm{O} 2 \mathrm{O}$. No doubt that make a real profit $\mathrm{O} 2 \mathrm{O}$ mode also need many companies continue to explore and practice. And constantly adjust management strategies and adapt to the market environment.

\section{References}

[1]Pruzhansky V. Luxury goods, vertical restraints and internet sales [J]. EUROPEAN JOURNAL OF LAW AND ECONOMICS. 2014,38(2): 227-246.

[2] Ortgies M, Remote control of electricity transmission and distribution, using Internet protocol [J]. Elektrizitaetswirtschaft. 2007,106(23):46-47.

[3]Sl Yang, Y Liao, CM Shi, CY Gao. Heuristics for solving an internet retailer's dynamic transshipment problem [J]. Expert Systems with Applications. 2014, 41(11): 5382-5389.

[4]Chuan HT, Khim YG, HH Teo, XYang. Response to Buyout Options in Internet Auctions [J]. IEEE Transactions on Engineering Management. 2014,61(2): 285-297.

[5]Yang H, Chen YX, Zheng LQ, Xu X, Cao X. Analysis of internet use behaviors among clinical medical students in China [J]. BMC MEDICAL EDUCATION. 2014,14(67):102-105

[6]Caldervvood Eric, Freathy Paul. Consumer mobility in the Scottish isles: The impact of internet adoption upon retail travel patterns [J]. TRANSPORTATION RESEARCH PART A-POLICY AND PRACTICE. 2014,59:192-203.

[7]Lee YM. An Impact that Service Quality Has for Customer's Repurchase in Internet Shopping Malls [J]. Korea Logistics Review. 2014,24(1):137-155.

[8]Korgaonkar P, Petrescu M, Becerra E. Shopping orientations and patronage preferences for Internet auctions [J]. International Journal of Retail \& Distribution Management. 2014,42(5): 352-368.

[9]Bijmolt T.H.A, Huizingh E.K.R.E, Krawczyk A. Effects of complaint behaviour and service recovery satisfaction on consumer intentions to repurchase on the internet $[\mathrm{J}]$. Internet Research. 2014,24(5):608-628.

[10]Van der Meulen N.S. You've been warned: Consumer liability in Internet banking fraud [J]. COMPUTER LAW \& SECURITY REVIEW. 2013,29(6): 713-718. 